\title{
Clare Gerada: The older doctor
}

\author{
Clare Gerada GP partner
}

Hurley Group, London, UK

I am at that age where increasing numbers of my friends are becoming grandparents. They talk of their joy at this new role-and about how caring for children seems easier this time around.

Grandparents are there to offer support, wisdom (preferably in small amounts), and the knowledge they have gleaned from "having done it before." They know how to accept the anxiety of the unknown and to deal with the fear of "getting it wrong." This resonates with me-not yet as a grandparent but as an older member of my profession.

When doctors reach a certain age we may not be able to work as hard as our younger counterparts or to cope as well after long days or nights on call. But we provide no less valuable a role in the lives of our organisations.

An increasing number of older doctors, however, are leaving work, ${ }^{12}$ many of whom still have much to offer, and a crucial balance is being lost from the NHS. These doctors are leaving prematurely for several reasons. Some are leaving because they cannot cope with the current demands of appraisal and revalidation; others cite the increasing pressure associated with inspection, regulation, and keeping up to date. Many others feel burnt out after decades of administering to sick people and may have begun to lose their compassion. Recently, problems with the NHS pension are leading many to retire early or reduce their hours. $^{3-5}$

\section{Refreshing the older workforce}

It is crucial that we find some way to retain and refresh this older workforce, which now includes myself. I am not suggesting that doctors should "work until they drop" or that standards should be lowered for older doctors-far from it. These doctors often leave rather than continue in clinical practice because of the excessive demands placed on them by regulatory and mandatory requirements. Regulations are part of the problem, but the working environment also has to change. ${ }^{6}$
As with families and societies in general, healthy workforces have transgenerational membership, where people of all ages are needed: the newly qualified doctors who are learning their trade and gaining confidence and competence; doctors in their middle years, who are leading change; and the older generation, who are in a position to transfer knowledge and provide stability.

Losing any generation can lead to a downward spiral. Critical staff losses will inevitably leave others having to work harder, increasing rates of burnout and resulting in more early retirements-and the cycle then repeats itself.

Doctors are a precious resource, expensive to train and difficult to replace. The challenge now is how to keep the older workforce energised, engaged, and effective. This would include more flexible working options and allowing doctors move away from mainly clinical duties to providing more support, teaching, mentoring, and other jobs of inestimable value to the profession. ${ }^{7}$

\section{Competing interests: See www.bmj.com/about-bmj/freelance-contributors.}

Provenance and peer review: Commissioned; not externally peer reviewed.

Moberly T. More hospital doctors are opting to retire early. BMJ 2018;362:k3744. 10.1136/bmj.k3744 30181157

2 Moberly T. Rise in GPs taking early retirement. BMJ 2018;360:k1367. 10.1136/bmj.k1367 29599207

$3 \quad$ Kmietowicz Z. Reform pension rules or doctors will reduce their hours, BMA warns chancellor. BMJ 2019;365:11885, 10.1136/bmi.l1885 31023657

4 Armstrong S, Goldstone AR. Three weeks to find £25 000: the NHS doctors remortgaging to pay punitive pension tax bills. BMJ 2019;364:I998. 10.1136/bmj.1998 30837244

5 Armstrong $\mathrm{S}$. Cuts to pension tax relief deepen retention crisis for senior doctors. BMJ 2019;364:I20610.1136/bmj.l206

6 Choudhry NK, Fletcher RH, Soumerai SB. Systematic review: the relationship between clinical experience and quality of health care. Ann Intern Med 2005;142:260-73. 10.7326/0003-4819-142-4-200502150-00008 15710959

7 Snashall D. Aging healthcare professionals. Occup Environ Med 1997;54:770-1. 10.1136/oem.54.11.770 9538346

Published by the BMJ Publishing Group Limited. For permission to use (where not already granted under a licence) please go to http://group.bmj.com/group/rights-licensing/ permissions 